\title{
Testing of the combined structural elements of support of a mine opening
}

\author{
Grygorii Gasii ${ }^{1, *}$, Olena Hasii $^{2}$, and Vita Klimenko ${ }^{2}$ \\ ${ }^{1}$ Sumy National Agrarian University, 40021, Sumy, Herasym Kondratiev Str., 160, Ukraine \\ ${ }^{2}$ Poltava University of Economics and Trade, 36014, Poltava, Koval Str., 3, Ukraine
}

\begin{abstract}
The stress-strain state of test specimens of the new combined system of support of a mine opening under imposed loads is studied. The test specimens are compound modular elements of the offered earlier combined system of support. Every single modular element is the regular quadrangular pyramid, consisting of a reinforced concrete slab and steel tube web members. The slab and web members are gathered in a complete element while concreting the slab. The tension sensor's method of experimental research is applied to the test of specimens. The test of specimens is carried out under the load imposed with a hydraulic press. The load is set so that to imitate service conditions, including the most adverse. Design features of the offered support and test specimens are presented. Details of the support and its elements, sizes, production technology and assemblies are briefly described. The test methodology of specimens and the analysis of the results are presented. The load-carrying abilities of test specimens under the concentrated force and uniform load are obtained. Break down of slab and connection between the web members and the slab are the results of the test of the specimens under the concentrated force and the uniform load respectively.
\end{abstract}

\section{Introduction}

For mine working depending on their purposes and also hydrological and geological conditions, several ways are used. Nevertheless, in all cases for mine working there is necessary to build supports - constructions for prevention of collapse of rocks or the soil and also maintaining the service condition and the design sizes and parameters of the mine openings. Currently, the profitability of a way of support is important. Supports have to provide reliability and at the same time to be easy in installation. In recent years, notable deterioration in mining-and-geological conditions is observed that gradually promotes the physical wear of the existing supports. In this case, it should be noted that the repair or installation of new supports is a labor-intensive process and demands big material inputs [1]. For example, the coal mining working experience shows that the cost of repair, service, and maintenance in-service condition of the supports can reach $10 \%$ of the cost of the coal. The arch hypothesis has a wide distribution for support designing. Even though the arches are effective structures to resist pressure from the soil it is not

*Corresponding author: gasiigm@gmail.com 
always possible to achieve sufficient results. Currently, the steel frame-arch supports are used for mine opening in most cases [2]. However, such structures have disadvantages. First of all, it is the complexity of ensuring the load-carrying ability of the support of a mine opening with a high mine pressure and unstable wall rock [3]. The anchor and anchor-frame supports are also applied to mine working [1], which also have disadvantages: labor input and complexity of works at installation of anchors; lack of the high-performance drilling equipment of domestic production; the need for the expensive explosion-proof compressor mobile equipment. Often, these disadvantages, when fields are developed with using mentioned supports, turn mine working into unprofitable because there is a need in enormous monetary, and human resources [3]. The current state of the mining industry given, the creation of the new kind of supports of mine opening with the minimum expenses is the rather actual problem. In the studies already mentioned above, as in this study, the attention to the need for the development of new systems of supports is also focused. In this regard, the new structural concept of the combined system of support to mine working is developed. It is expected that this support will be resistant to the side pressure of soil, and will be less labor-consuming in construction, and also will promote the reduction of consumption of steel. The complex of theoretical and experimental researches, including the review of the existing structures of supports of mine opening, the analysis of their advantages and disadvantages, studying of reports of inspections, etc. is for this purpose executed [1-7]. Therefore the new system of support consisting of the combined modular elements [8] is developed. Preliminary experimental researches $[9,10]$ and the feasibility study [11] demonstrate the efficiency of the offered constructive scheme. However, there are still many unexplored issues related to the design of the proposed support. Some such questions are studying of stress-strain state of the combined elements and justification of the efficiency of their constructive concepts. In this regard, the purpose of the work is to establish the regularity of development of strains of extreme filaments in characteristic cross-sections of test specimens from load rate as well as to establish a load-carrying ability and actual damage of test specimens.

\section{Methods}

The well-known and approved experimental research technique of the full-scale test specimens under the load enclosed via a hydraulic press is used to solve the delivered problem. The experimental technique provides studying of the stress-strain state of test specimens with tension sensors and dial indicators as well as breaking down the test samples to establish their actual damage. The adopted experimental research technique also allows receiving strain-load relations in extreme filaments of characteristic cross-sections of test specimens.

\section{Results and discussion}

\subsection{Design of the test specimens}

As it is already noted, the offered structures are developed for application in the mining industry as the carrying structures of support of the mine opening (Fig. 1, a). Besides, the offered structure can be applied for the installation of retaining walls (Fig. 1, b), walls of wells (Fig. 1, c), etc. The combined structural element (module) is the making element of the offered structure. The module is made of a slab and web members and has a wedge 
form. The slab can be a square (Fig. 2) or a rectangular shape (this one is not considered) [10]. The slab can be reinforced by concrete or steel and concrete composite.

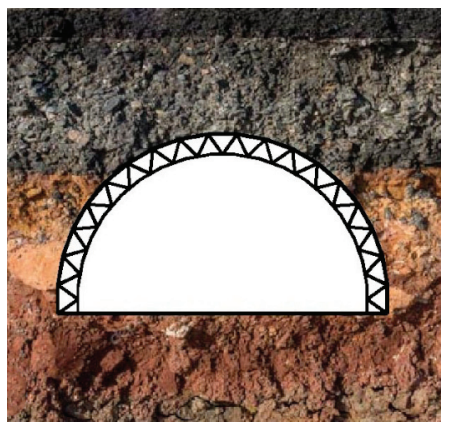

a)

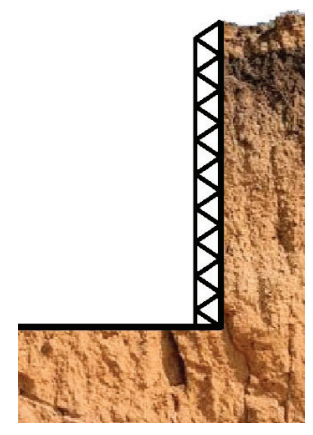

b)

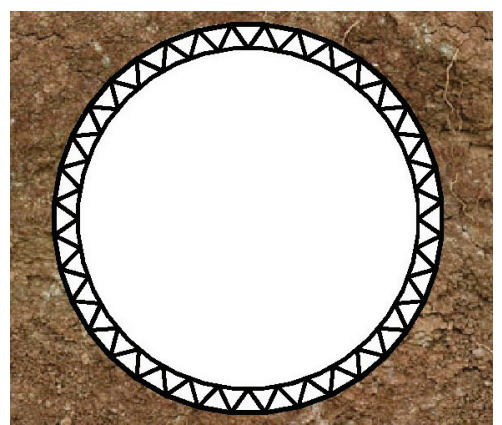

c)

Fig. 1. Using the offered structures in the mining industry: a) support of a mine opening; b) retaining walls; c) walls of wells (top view).

The web members of the module (positions 2 and 3 in Figure 2) are fabricated from steel tubes and form a spatial lattice, like "grid structure". Generally, web members are hollow items, but if there is a need to increase the load-carrying ability of the module, they are filled with concrete. To the production of a lattice, tubes in different diameters according to GOST 10707-80 or other tube standards for the mining industry are used. The bar mesh ( $\mathrm{C}-1$ and $\mathrm{C}-2$ in Figure 2$)$ are fabricated from the bars at least class A400. The inserts from sheet steel (position 1 in Figure 2) play the role of the connecting links between a slab and steel tube web members. The bar meshes and embedded parts reinforce the slab.
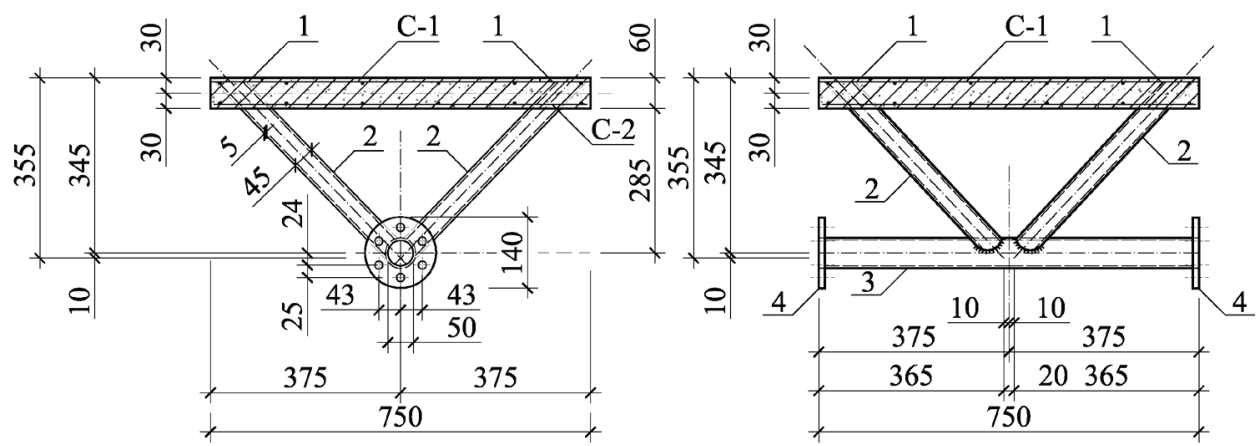

Fig. 2. Details of the test specimen of the square combined structural element (module) for mine opening: 1 - insert from steel sheet; 2 and 3 - steel tube web members; 4 - the flange for bolted connection; $\mathrm{C} 1, \mathrm{C} 2$ - bar meshes.

In more detail the information about offered support and ways of production of the combined structural elements can be found in the article [12]. The sizes of combined structural elements and their components are defined by calculation in accordance with codes of design steel, reinforced concrete as well as steel and concrete composite structures [13 - 15]. The angle between steel tube web member and its alignment can be accepted from $30^{\circ}$ up to $60^{\circ}$. It is well-known from grid structures designing. But in previous studies [8 - 12] and the current study angle of $45^{\circ}$ has been used. From experience in designing it is known that such angle is the most favorable angle for grid structures, as well as it is used in many similar building structures [16].

The offered support is assembled from modules through connections, the design of 
which depends on the shape of the support, for example, Figure 2 shows the module for the flange bolted connection. The combined structural elements are collected into the support that can have both flat and curvilinear shapes (Fig. 1). The quantity of modules for support assembling is defined by calculation based on the feasibility study and trial design. The determination technique of the modules quantity is similar to the well-known space grid structures, which takes into account such characteristics of a structure as span, depth of the module and an angle for web members [17].

Production of the combined structural elements is carried out by monolithic or prefabricated (in this work is not considered) ways. The choice of a method depends on the size of the mine opening and available equipment. The feature of monolithic production of modules lies in the way of concreting of elements. Concreting carried out when the skeleton of the module lays turned side on the site instead of the proper location (Fig. 4, a). In this case, web members play the role of the bearing and reinforcing details. In this way, the integrity and solidity of the module are reached. When the prefabricated way is selected, the module production follows to that order: firstly, the slab is concreted, then the web members are connected to inserts by bolts (such decision is described in work [10]). The application of the offered support for mine working leads to reach some economic benefit, no matter what way of module production is selected [11]. In addition, there is no need for a wide range of timbering and special racks, as it often happens during concreting in the permanent position of a structure (not to confuse with monolithic production of modules). In more detail the information about the design features of the offered support can be found in the monograph [18] or guide [19].

\subsection{The experimental research technique of the test specimens}

The development of the experimental research technique is caused by insufficient information about of the stress-strain state of the making elements of the offered support, as well as their behavior under the load. It is considered that the load-carrying ability of elements depends on various impacts, in particular on constructive schemes, the geometrical sizes and physic-mechanical properties of materials - steel and concrete, a way of loading, etc.

By drawing up the program of experimental researches several tasks are set, among which to reveal features of the behavior of elements of the offered supports under the load; to check whether the combined action of a reinforced concrete slab and steel tube web members is ensured; to define the stress-strain state of elements under load; to define the load-carrying ability of elements of the offered supports; to define the strain-load relations and ultimate limit state; to obtain key point displacements while testing the specimen; to obtain actual damage of test specimens, etc.

For obtaining experimental data, which allows getting sufficiently performance evaluation of the elements of the offered supports the test specimens of the combined structural elements are designed and made (Fig. 2). Following the technique of experimental researches, control samples are made of materials of the test specimens. There are concrete cubes of $150 \times 150 \times 150 \mathrm{~mm}$; the strips, which are cut out from tubes and sheet steel; segments of bar reinforcements. The control samples are made to obtain the physicmechanical properties of materials of the test specimens. The control samples are tested at the same time as test specimens. The test specimens are tested in different ways of loading - under concentrated (Fig. 3) and uniform load (the load is imposed on the entire surface of a slab).

The concentrated force imitates earth pressure on supports, which includes a rock as well as uneven pressure of soil (that is a frequent cause of the destruction of the supports [2]), and uniform load - the pressure on supports the uniform massif of soil. 
It should be noted that the accepted ways of test specimens loading imitate the worst boundary conditions, which can appear during the operation of the offered supports. It allows estimating a resource of load-carrying ability the offered supports objectively. Loads are imposed on a slab with a press through the spreader discs (Fig. 4).

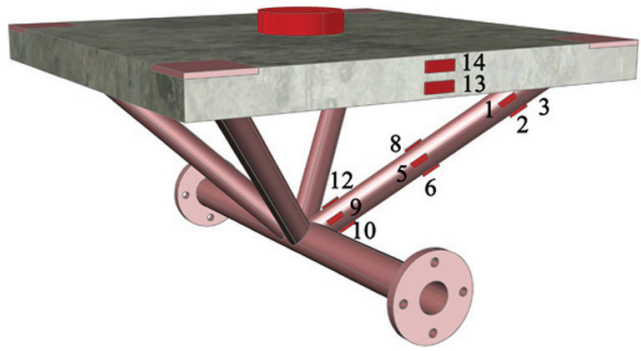

a)

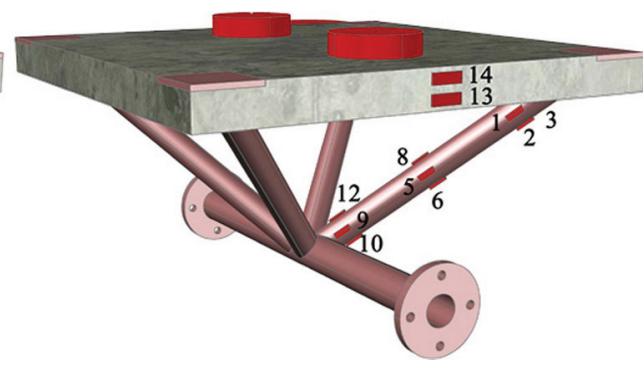

b)

Fig. 3. The ways of test specimens loading: a) one concentrated force; b) two concentrated forces, where $1,2, \ldots, 14$ - numbers of tension sensor.

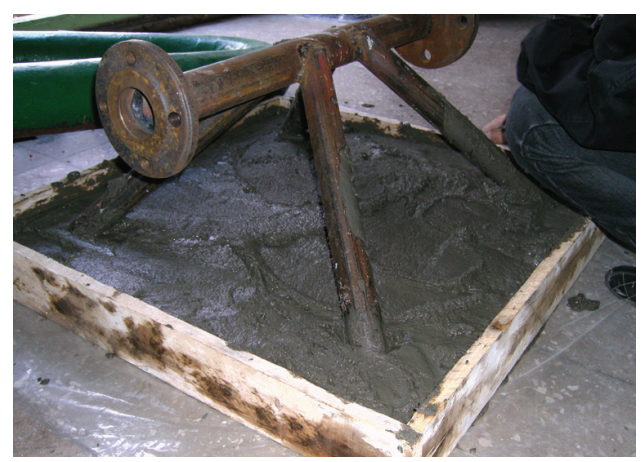

a)

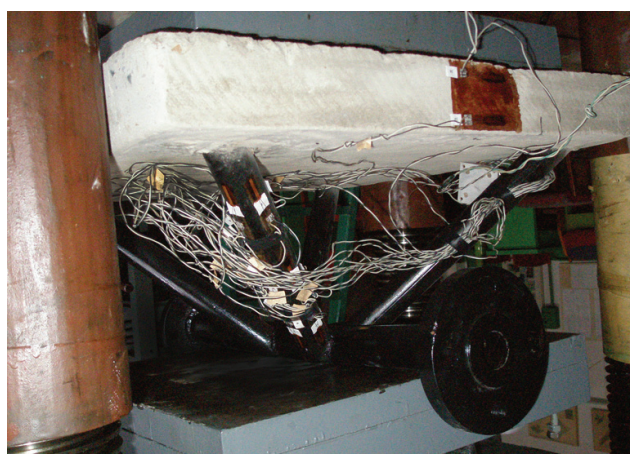

b)

Fig. 4. It is the combined structural elements while production (a) and testing under uniform load (b).

\subsection{Test results of test specimens}

The strains and displacements are measured in specific points of elements of the support as a result of the tests. Strains are measured via tension sensors with the multichannel measuring system VNP8 and also dial indicators. Tension sensors are fastened not only on web members and flank sides of the slab as Figure 3 shows, and also on the side of the slab as Figure 5 (a) shows.

Placement of tension sensors on the side where the load is imposed is impossible because they will be damaged by spreader discs. Anyway, the placement of tension sensors allows measuring strains correctly and analyzing the stress-strain state of test specimens objectively. Based on the features of materials and experience of experimental researches for measurement of strains are used tension sensors of different lengths: $50 \mathrm{~mm}$ - for concrete; $30 \mathrm{~mm}$ - for steel.

Following the experimental researches program, the test specimens are broken down (Table 1). It is considered that test specimens lose load-carrying ability when concrete is broken down in a spot of force application, or connections are broken down, or the yield strength in steel members is reached. As a result of the tests, the value of the strain in the extreme filament of the cross-sections are obtained and some strain-load relations are plotted (Fig. 5, b). 


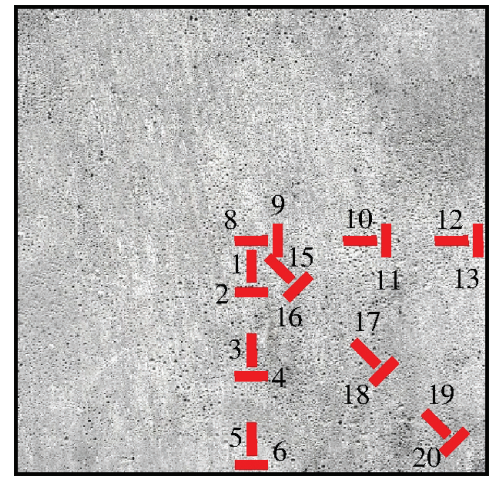

a)

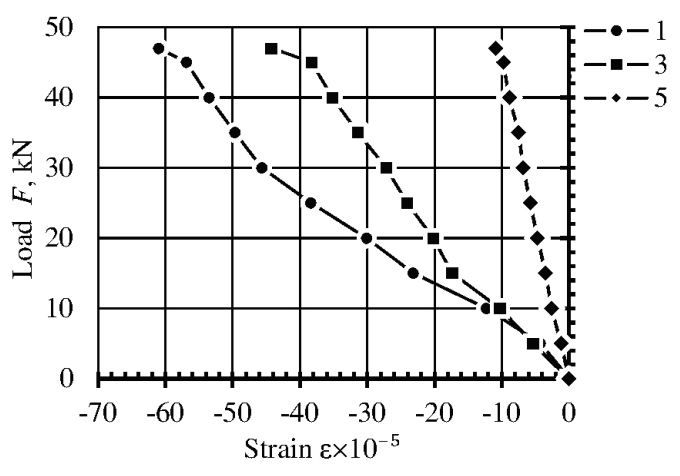

b)

Fig. 5. The placement of tension sensors on a concrete slab (web members are conventionally not shown) (a), where 1, 2, .., 20 - numbers of tension sensors; and an example of strain-load relation for a slab under the concentrated force, which is applied on the center spot of a slab, where 1, 3 and 5 - numbers of tension sensors (b).

\subsection{Analysis of the test results of the test specimens}

The analysis of the test results shows in general that combined structural elements are in the elastic behavior during the test. This stress-strain state of elements under such loadings, in general, is usual and corresponds to the well-known patterns. It means that the technique (the current codes for calculation of carrying structures [13-15, 19]) that is used for the test specimens designing is an acceptable one. It means that at this stage of researches there is no need to develop the theory of calculation of the offered supports of mine opening.

It should be noted the loads under which the concrete is broken down did not cause the inelastic deformation of steel elements. Each test specimen under the concentrated forces is collapsed as a result of the concrete slab breakdown in a spot of force application (Fig. 6, a). However, at the same time, the load-carrying ability of tested samples under uniform load has exceeded the load-carrying ability of tested samples in the previous case at 6 times. The tested samples are collapsed as a result of reaching yield strength in steel elements as well as due to the destruction of the connection between web members and slabs (Fig. 6, b). The experimental data shows the offered structures are not equally effective under the different loading ways (Table 1). That is not something unusual because the different loading ways lead to different inner forces distributions in structural elements.

Table 1. Results of tests of test specimens.

\begin{tabular}{|c|c|c|c|}
\hline The way of loading & $\begin{array}{c}\text { Test specimen } \\
\text { dimensions, } \mathrm{mm}\end{array}$ & Causes of failure & $\begin{array}{c}\text { Load, } \\
\mathrm{kN}\end{array}$ \\
\hline $\begin{array}{l}\text { The concentrated force is applied } \\
\text { at the center spot of the slab via } \\
\text { spreader disc } 150 \mathrm{~mm} \text { in diameter }\end{array}$ & $750 \times 750 \times 355$ & $\begin{array}{c}\text { Concrete is broken } \\
\text { down }\end{array}$ & 49.78 \\
\hline $\begin{array}{l}\text { Two concentrated forces are } \\
\text { applied at the spots, which divides } \\
\text { the slab into three equal-area } \\
\text { stripes along the axis }\end{array}$ & $750 \times 750 \times 355$ & $\begin{array}{c}\text { Concrete is broken } \\
\text { down }\end{array}$ & 63.76 \\
\hline Uniform load is applied on the slab & $750 \times 750 \times 355$ & $\begin{array}{c}\text { Yield strength is } \\
\text { reached; connections are } \\
\text { broken down }\end{array}$ & 362.97 \\
\hline
\end{tabular}


So, for example, under the concentrated forces, the carrying purpose is performed by the slab, which is supported by four points. But, it should be noted that the slab of the module, which is in the support has limited displacements and strains by the nearby modules. Accordingly, the slab behavior is the same as an edge supported slab, but it does not change the design diagram because imposed loads cause the bending moments in two axes that are mutually perpendicular. Since the permanence of the combined action between the modules is not guaranteed and the connection can be broke that's why it is recommended to consider the slab as a slab supported on four points because it is the worst boundary conditions. But in the module that is under uniform load, the most stressed elements are the steel tube web members that are stressed by inner forces that are passed by the slab thought the connection. That inner forces distribution is caused by that the load, which is imposed by the press through the big rigid steel disc not cause strains of the middle part of the slab more than the strains of the edges.

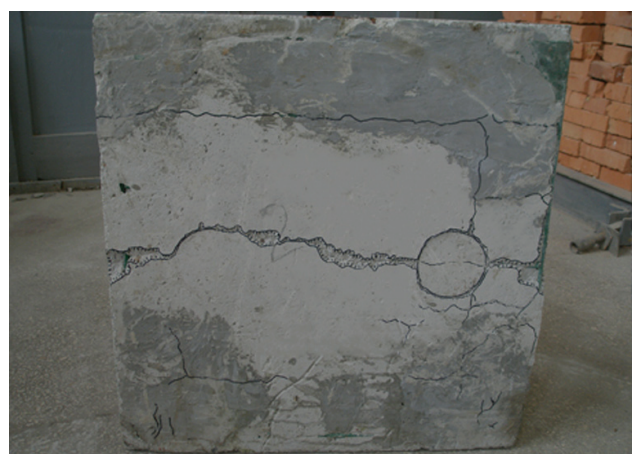

a)

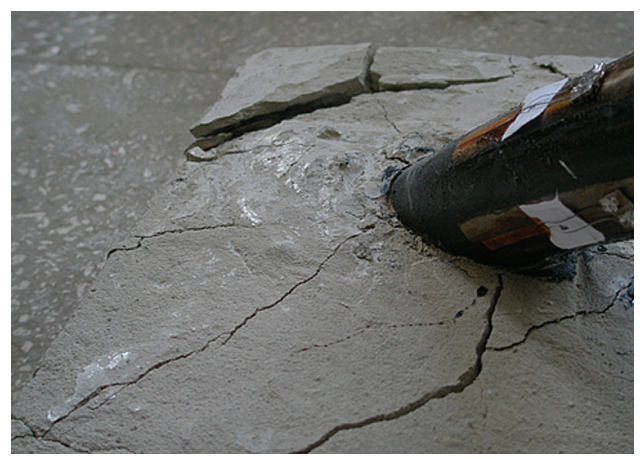

b)

Fig. 6. Destruction of test specimens are caused by the concentrated forces (a) and uniform load (b).

It should be noted that during testing at the load that is $85 \%$ from design ultimate load still elastic work of materials is observed. However, at the subsequent levels of loading, the yield strain in steel elements, destruction of connection between the web members and the slab, and increasing cracks width are observed. Also, it should be noted that all components (web members, reinforcement, inserts, and slab) of the combined structural elements are in combined action during all the loading stages in common up to total failure. It demonstrates the efficiency of the structural concept of the combined structural elements.

\section{Conclusions}

As a result of the experimental researches of the combined structural elements of a mine opening the goal is reached, in particular, the new data is established (it is the actual strains depending on the load in characteristic sections; it is the load-carrying ability and the actual damage of test specimens), which give understanding about features of structure behavior under loading, and the stress-strain state and also confirm the efficiency of the constructive concept. It is established that under the concentrated forces, the test specimen destruction comes when the concrete slab is broke down at the place of forces application. The test specimens under uniform load lose the load-carrying ability that is caused by the destruction of connection between a reinforced concrete slab and steel tube web members.

It should be noted that the slab concrete broke down in the place of the force application is not dangerous of the support because this damage is local and has no effect on the loadcarrying ability of the support in general. At the same time, the destruction of connections 
between the web members and the slabs is dangerous because this could lead to the destruction of support within a certain location.

\section{References}

1. A. F. Bulat. Visnyk of the National Academy of Sciences of Ukraine, 1, 74-79 (2014)

2. G. Storchak, A. Korol, S. Gapieiev. Up-to-date resource- and energy-saving technologies in mining industry, 1, 143-152 (2013)

3. O. Khalimendik, G. Storchak, O. Khalimendik, V. Pustoviy. Up-to-date resource- and energy- saving technologies in mining industry, 2, 157-165 (2013)

4. Aksenov, V. V., Kazantsev, A. A., Dortman, A. A. (2012). Obzor suschestvuyuschih tipov krepi gornyih vyrabotok $\mathrm{i}$ analiz ih vozmozhnosti primeneniya $\mathrm{v}$ geovinchesternoy tehnologii. Gornyiy informatsionno-analiticheskiy byulleten (nauchno-tehnicheskiy zhurnal), 3, 130-137.

5. Karhapolov, Yu. V. Lohunova, A. O. (2015). Analyz tekushcheho sostoianyia protiazhennykh hornykh vyrabotok uholnykh shakht HP Selydovuhol. Visnyk Kryvorizkoho Natsionalnoho Universytetu, 39, 97-101

6. T. Wieja. Journal Biuletyn of Polish Society for Geometry and Engineering Graphics, 30, 63-72 (2017).

7. Tereschuk, R. N., Grigoriev, A. Ye. (2014). Examining the state of excavations in the mines of Ltd "Dobropolyeugol". Zbirnyk Naukovykh Prats DonNTU, 1, 68-85

8. Gasii, G. M. (2014). Technological and design features of flat- rod elements with usage of composite reinforced concrete. Metallurgical and Mining Industry, 6 (4), 23-25

9. Storozhenko, L. I., Gasii, G.M. (2014). Experimental research of strain-stress state of ferrocement slabs of composite reinforced concrete structure elements. Metallurgical and Mining Industry, 6 (6), 40-42

10. Storozhenko, L. I., Hasii, H. M. (2015). The new composite designs for mine tunnel support. Naukovyi Visnyk Natsionalnoho Hirnychoho Universytetu, 4, 28-34 (2015)

11. Gasii, G., Hasii, O., Zabolotskyi, O. (2017). Estimate of technical and economic benefits of a new space composite structure. In: MATEC Web of Conferences, 116, 02014. https://doi.org/10.1051/matecconf/201711602014

12. G. M. Gasii. Production of full-scale experimental modular specimens of the steel and concrete composite cable space frame. Inżynieria bezpieczeństwa obiektów antropogenicznych, 3-4, 13-17 (2017)

13. DBN V.2.6-98:2009. Konstruktsii budynkiv $i$ sporud. betonni ta zalizobetonni konstruktsii. Osnovni polozhennia (Minrehion Ukrainy, 2011)

14. DBN V.2.6-198:2014. Steel structures. Design code (Minrehion Ukrainy, 2014)

15. DBN V.2.6-160:2010. Konstruktsii budynkiv i sporud. stalezalizobetonni konstruktsii. Osnovni polozhennia (Minrehion Ukrainy, 2010)

16. Shmukler, V.S., Krasnov, S.N. (2017). The use of modular elements in the construction of pedestrian bridges. Naukovi Visti Dalivskoho Universytetu, 12

17. W. F. Chen, E. M. Lui. Handbook of structural engineering (CRC press, 2005)

18. Hasii, H. M. (2018). Prostorovi Strukturno-Vantovi Stalezalizobetonni Konstruktsii Monohrafiia. Poltava: ASMI

19. Hasii, H. M. (2018). Rekomendatsii Do Proektuvannia Prostorovykh StrukturnoVantovykh Stalezalizobetonnykh Konstruktsii. Poltava: ASMI 